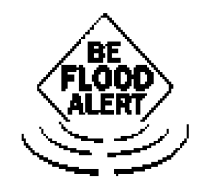

NATIONAL FLOOD INSURANGE PROGRAM
- This publication was written by Regina Fegan and Michael T. Olexa, Food and Resource Economics Department, University of Florida.

- This document, IFAS publication DH0436, was published June 1998 revised May 2003. It is part of The Disaster Handbook, a component of the Comprehensive Disaster Preparedness and Recovery Education Module: General editor: Carol J. Lehtola, Agricultural and Biological Engineering Department, Institute of Food and Agricultural Sciences, University of Florida, Gainesville, Florida 32611.

For information about products and ordering, please visit:

$<$ http://disaster.ifas.ufl.edu>.

UF/IFAS Extension publications are available at the EDIS Web site: $<$ http://edis.ifas.ufl.edu>.

- The Institute of Food and Agricultural Sciences is an equal opportunity / affirmative action employer authorized to provide research, educational information, and other services only to individuals and institutions that function without regard to race, color, sex, age, handicap, or national origin. For information on obtaining other extension publications, contact your county Cooperative Extension Service office. Florida Cooperative Extension Service / Institute of Food and

Agricultural Sciences / University of

Florida / Christine Taylor Waddill, Dean.

\section{How the National Flood Insurance Program (NFIP) Works}

The Federal Insurance and Mitigation Administration (FIMA) makes flood insurance available in areas where the appropriate public body has adopted adequate floodplain management regulations for its flood-prone areas. Community participation is voluntary, although some states require NFIP participation as part of their floodplain management program. Communities who wish to participate in the NFIP must fulfill two phases:

- Phase 1. Emergency Program of the NFIP

$\circ$ Phase 2. Regular Program of the NFIP
1. Community applies to participate in the NFIP:

a. Through community interest in flood insurance, or

b. Notification from FEMA that it contains one or more Special Flood Hazard Areas (SFHA). Application includes adopted resolutions or ordinances to minimally regulate new construction in SFHA.*

*A flood-prone community that does not apply for participation in the NFIP within 1 year of notification is ineligible for federal or federally-related financial assistance for acquisition, construction or reconstruction of insurable buildings in the SFHA.

2. FEMA authorizes the sale of flood insurance in the community up to the Emergency Program limits. FEMA assesses the community's degree of flood risk and development potential.

The Disaster Handbook 


\begin{tabular}{|l|l|l|}
\hline \multicolumn{3}{|c|}{ Emergency Program Flood Insurance Coverage Limits } \\
\hline & Building & Contents \\
\hline Single family dwelling & $35,000^{*}$ & 10,000 \\
\hline Other residential & $100,000^{*}$ & 10,000 \\
\hline Non-residential & $100,000^{*}$ & 100,000 \\
\hline $\begin{array}{l}\text { * Under the Emergency Program, higher limits of building } \\
\text { coverage are available in Alaska, Hawaii, the U.S. Virgin } \\
\text { Islands, and Guam. }\end{array}$ \\
\hline
\end{tabular}

3. If appropriate, FEMA arranges for a study of the community to determine base flood elevations and flood risk zones.

Consultation with the community occurs at the start of and during the study. Communities with minimal or no flood risk are converted to the Regular Program without a study.

4. FEMA provides the studied community with a Flood Insurance Rate Map delineating base flood elevations and flood risk zones. The community has 6 months to adopt base flood elevations in local zoning and building code ordinances, and to meet other requirements.

5. Community adopts more stringent ordinances, and FEMA converts the community to NFIP's Regular Program (below).

\section{Phase 2. Regular Program of the NFIP}

1. FEMA authorizes the sale of additional flood insurance in the community up to the Regular Program limits.

\begin{tabular}{|l|l|l|}
\hline \multicolumn{2}{|c|}{ Regular Program Flood Insurance Coverage Limits } \\
\hline & Building & Contents \\
\hline Single family dwelling & 250,000 & 100,000 \\
\hline Other residential & 250,000 & 100,000 \\
\hline Non-residential & 500,000 & 500,000 \\
\hline
\end{tabular}

The Disaster Handbook Institute of Food and Agricultural Sciences University of Florida
How the National Flood Insurance Program (NFIP) Works Section 4.36

Page 2 
2. Community implements adopted floodplain management measures.

3. FEMA arranges for periodic community assistance visits with local officials to provide technical assistance regarding complying with NFIP floodplain management requirements.

4. Local officials may request flood map updates as needed. FEMA evaluates requests, encourages cost-sharing, and issues revised maps as priorities dictate.

\section{Sources for This Publication}

How the NFIP Works

Federal Emergency Management Agency. Access on the Web at: $<$ http://www.fema.gov.nfip.how.htm>

This publication is designed to provide accurate, current, and authoritative information on the subject. However, since the laws, regulations, administrative rulings, and court decisions on which it is based are subject to constant revision, portions of this publication could become outdated at any time. This publication is distributed with the understanding that the authors are not engaged in rendering legal advice or opinions, and the information contained herein should not be regarded, or relied upon, as a substitute for legal advice or opinion. For these reasons, the utilization of these materials by any person

constitutes an agreement to hold harmless the authors, the Institute of Food and Agricultural Sciences and the University of Florida for any liability claims, damages or expenses that may be incurred by any person as a result of reference to or reliance on the information contained in this fact sheet.

The Disaster Handbook How the National Flood Insurance Program (NFIP) Works Institute of Food and Agricultural Sciences Section 4.36 University of Florida 